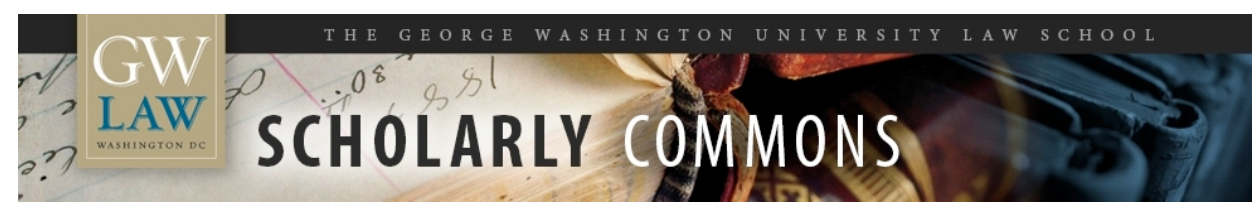

GW Law Faculty Publications \& Other Works

Faculty Scholarship

2012

\title{
Comparative Administrative Law
}

\author{
Francesca Bignami \\ George Washington University Law School, fbignami@law.gwu.edu
}

Follow this and additional works at: https://scholarship.law.gwu.edu/faculty_publications

Part of the Law Commons

\section{Recommended Citation}

Francis Bignami, "Comparative Administrative Law," in The Cambridge Companion to Comparative Law 145-170. (Mauro Bussani and Ugo Mattei eds., 2012).

This Chapter is brought to you for free and open access by the Faculty Scholarship at Scholarly Commons. It has been accepted for inclusion in GW Law Faculty Publications \& Other Works by an authorized administrator of Scholarly Commons. For more information, please contact spagel@law.gwu.edu. 


\section{THE GEORGE WASHINGTON UN I V ERS I T Y L W SCHOOL}

Public Law and Legal Theory Paper No. 2012-115

Legal Studies Research Paper No. 2012-115

\section{Comparative Administrative Law}

\section{Francesca Bignami}

2012

The Cambridge Companion to Comparative Law 145-170. (Mauro Bussani and Ugo Mattei eds., 2012).

This paper can be downloaded free of charge from the Social Science Research

Network: http://ssrn.com/abstract=2171307 


\title{
COMPARATIVE ADMinisTrative LAW
}

\author{
Francesca Bignami \\ George Washington University
}

\section{Table of Contents}

\author{
1. Overview
}

2. Public Administration

3. Administration and the Courts

3.1. Systems of judicial review

3.2. Principles of administrative action

4. Administration and Organized Interests

5. Administration and the Public

6. The Globalization of Administrative Law

\section{Overview}

The field of administrative law is inextricably bound to two phenomena that trace their origins to the nineteenth century: the rise of large state bureaucracies designed to fulfill a complex array of societal needs and the development of liberal democratic norms of social organization and public authority. Much of administrative law can be understood as an attempt to work out the tension inherent in these two phenomena: the recognition that the attainment of public purposes is contingent on a cadre of full-time employees, paid by the public purse and loyal to the state, and, at the same time, the belief that public authority is legitimate only if embedded in democratic politics and liberal societies. To put it more succinctly, these are the objectives, on the one hand, of neutrality and expertise, and, on the other hand, of democracy and liberal rights. 
The common aspiration of making public administration both capable and accountable serves as the springboard for the comparative analysis in this chapter. I begin with a discussion of what, in the law, is taken to be the hallmark of modern bureaucracy - the legal guarantees of civil service employment - together with national variations in the professionalization of administration and contemporary efforts to cut back on civil service guarantees. I then turn to three important types of accountability: the contestation of administrative action before the courts, the involvement of organized interests in administrative policymaking, and informal accountability to the general public through parliamentary ombudsmen and transparency guarantees. These categories serve as a framework for exploring the similarities and differences that shape contemporary administrative law systems. The chapter concludes with the increasingly important phenomenon of the globalization of administrative law and the rapid migration of administrative principles across legal systems throughout the world, both national and international. In line with the intellectual purpose of this volume, I have omitted topics that have traditionally been considered peripheral to the field or that fall at the intersection with other disciplines, for instance the constitutional powers of the executive branch over public administration and the empowerment of private groups through selfregulation, and refer the reader to the bibliography at the end of the chapter for guidance.

\section{Public Administration}

One of the defining elements of bureaucracy is civil service employment: the selection and promotion of public officials based on merit and insulated from political influence through tenured employment. ${ }^{1}$ The legal guarantees of civil service employment emerged to serve multiple ends: autocratic rulers seeking to consolidate their authority (Prussia), political elites adapting the instruments of government to the demands of industrialization and urbanization (Britain), and government reformers intent on shielding administration from the instability and incompetence of party-patronage appointments (France and the United States). In Europe, Japan, and North America, civil service safeguards were introduced over the course of the nineteenth century: beginning in the 1840s in France, 1870 in Britain, 1873 in Prussia, 1882 in Canada, 1887 in Japan, and 1883 in the United States. 
Modern civil service laws are designed to render public employees independent of partisan politics and competent to perform the business of the nation. Some legal systems go so far as to constitutionalize this ambition, including the Italian Constitution (Articles 97 and 98) and the German Basic Law (Article 33). The core features of civil service employment are: (1) life tenure absent grave misconduct; (2) merit-based recruitment; (3) promotion based on a mixture of seniority and merit (often accompanied by independent civil service commissions); (4) pay scales and benefits that are more standardized than in private enterprise; and (5) restrictions on political activity, speech, and union activities, although these are far less common now than in the past.

Notwithstanding the common impulse to develop a professionalized public administration, there remain significant differences in the degree to which recruitment is professional or political. At the top echelons of the bureaucracy, political appointments are more extensive in the United States than in other countries, on the theory that electoral winners should have an opportunity to impose a new set of priorities on government administration through the selection of high-level personnel. ${ }^{2}$ There are also significant differences in the extent of patronage appointments at the lower levels of the bureaucracy. Some countries appear to be particularly vulnerable to party-based infiltration of the public administration, notwithstanding a legal commitment to an independent, professionally competent civil service. Italy represents but one example of this phenomenon. ${ }^{3}$ A number of mechanisms, related to the historically weak nature of party competition, have enabled political parties and party-affiliated trade unions to circumvent the civil service system and carve out the public administration among themselves. These mechanisms include the unofficial assignment of government sectors to certain political parties - for instance, in the past, the Ministry of Agriculture to the Christian Democrats - and the recruitment of personnel through temporary contracts, which are then converted into permanent employment by law or government decree.

The past twenty years or so have witnessed a number of challenges to the traditional model of civil service employment. ${ }^{4}$ The most important is the wave of New Public Management reforms that hit most democracies the 1980s. Reformers in this school have sought to render the public sector more efficient by making the terms of public sector employment - pay, benefits, and promotion-more flexible and by tying 
them more closely to performance indicators. Even more radically, various service delivery functions have been taken away from government administration and are now handled by firms operating in the private sector. The scope of these reforms, however, varies dramatically. Privatization, for instance, is far less pervasive in Europe than in the United States, where core state functions such as running prisons and conducting military operations have been out-sourced to private contractors. ${ }^{5}$

\section{Administration and the Courts}

\subsection{Systems of judicial review}

With the emergence of bureaucratic power in the nineteenth and early twentieth centuries came the question of justice. What was to be the relationship between the old mode of exercising public authority, through trials and courts, and this new form of state power, designed to expeditiously raise taxes, undertake public works, protect public health, and more? The right to contest administrative decisions in a trial-like proceeding before a state official removed from the original determination emerged in both civil law and common law systems as critical to the legitimacy of administrative authority. At the same time, what is generally understood to be the major difference between administrative law systems also took shape: jurisdiction vested in the ordinary courts in England versus litigation before specialized state officials connected to the executive branch in France.

The origins of the common law-droit administratif divide are extremely complex and have been the object of numerous distinguished studies. ${ }^{6}$ For our purposes, it is enough to recall the very different historical circumstances surrounding the rise of bureaucracy and administrative law in France and England. In France, the drive to consolidate absolute authority in the seventeenth and eighteenth centuries was marked by intense conflicts between the royal officers responsible for administering the provinces (intendants) and the powerful regional courts in the hands of local elites (Parlements). In an attempt to insulate the decisions of the intendants from interference by the Parlements, legal oversight was entrusted to a special body directly controlled by the monarchy (Conseil du Roi). The system of a specialized review body was borrowed during the French Revolution, albeit motivated by a very different republican theory aimed at 
destroying the special privileges and vested interests of the Parlements of the Ancien Régime and ensuring that government officials would not encounter resistance from the old elites in carrying out the will of the people. Napoleon, in turn, embraced this system with the founding of the Council of State (Conseil d'État). It was at this time that the distinctive French separation of powers doctrine was born, according to which "to judge the administration is still to administer" (juger l'administration c'est encore administrer): judicial review by the ordinary courts represented an encroachment upon the executive power and therefore oversight had to be entrusted to a specialized body connected with the executive branch.

By contrast, in England, the business of government was handled by local elites with relatively little central involvement until well into the nineteenth century and appeals against government officers were heard by courts of general jurisdiction based on the same system of common law writs devised for private disputes. Although the Stuarts made a bid to improve royal control by creating a separate set of prerogative courts with jurisdiction over complaints against government officers, the attempt came to end with the victory of Parliament and the common law bar in the Revolutionary Settlement of 1688. At that time, the hated prerogative courts were abolished and the powers and independence of common law judges were formally established by act of Parliament. Later, when a substantial, centralized bureaucracy emerged, largely in response to nineteenth-century industrialization, the stature of the common law was such that there could be no question of ousting the courts and transferring administrative disputes to a separate body.

Let us explore the common law-droit administratif difference in more detail. In 1885, the English scholar Albert Venn Dicey famously proclaimed that in England, unlike France, there was no such thing called administrative law. ${ }^{7}$ Government officers could be held to account for their actions, like private individuals, before the ordinary courts of law. The same judges, applying the same rules and affording the same rights and remedies, had the power to decide both suits against the government and purely private disputes. Dicey argued that by treating public administration and private individuals on the same footing, the English system did a better job of safeguarding basic liberties and therefore was superior to the French one. 
This characterization of the English system of legal redress has been rightly debunked as inaccurate, not only from the perspective of the law as it has evolved today but also at the time it was pronounced. For instance, the statute of limitations for tort actions against public officials was six months, compared to the six years for similar actions between private parties, and was only extended by the Law Reform (Limitation of Actions) of 1954. It is true, however, that the practice of common law adjudication did produce a marked tendency to deny any categorical difference between public and private law and a natural overlapping of legal concepts, writs, and forms of redress between cases brought against private parties and those brought against the government. ${ }^{8}$ Today, with the elaboration of numerous legal doctrines specific to administration, the creation of a specific procedure for judicial review, the widespread resort to administrative tribunals (explained below), and the establishment of a special section of the ordinary courts devoted to administrative law, it is evident that even in England, administrative law is a field apart from private law. The main vestiges of the original model that have survived are to be found in the area of government torts and public contracts, which are considered part of the general law of torts and contracts, and in the continuing power of common law courts to hear, in the last resort, cases brought against the government.

In France, the Council of State (Conseil d'État) was originally established by Napoleon. ${ }^{9}$ Then, as now, the Council of State had the dual function of drafting government laws and rules and hearing cases against government administration. Originally, the Council of State's dispute-resolution function was subject to extensive limitations, but by the time of the Third Republic most had been abolished and the Council of State had become a powerful and respected arbiter of complaints against the government.

Institutionally, the critical difference between the Council of State and the judicial branch is the system of recruitment and management of personnel, which gives rise to pronounced cultural and sociological affinities between the Council of State and public administration. Members of the Council of State are selected from graduates of the École Nationale d'Administration, the elite, state-run school designed to train the uppermost echelons of the civil service (about two-thirds) and from the ranks of experienced individuals already serving in the administration, either in the lower administrative courts 
or in the upper ranks of the civil service (about one-third). This stands in contrast to the judiciary, which is populated with law school graduates who receive professional training at the state-sponsored school for the judiciary. Moreover, at any given point in time, about one-third of the members of the Council of State are serving elsewhere in the public administration, in ministerial cabinets, public enterprises, and other government offices. The last distinguishing feature of the Council of State is the mix of functions performed by its members. There are five administrative sections, responsible for giving technical advice on legislation and regulation, and one adjudicatory section, which hears administrative law cases, and members are commonly assigned to both an administrative section and the adjudicatory section. It is also important to underscore what does not separate the Council of State from the judicial branch-independence. True, members of the Council of State, unlike the judiciary, are not formally guaranteed permanence in office (inamovibilité), which means that in theory they can be transferred from one post to another for any reason. In practice, however, this never occurs and it is universally acknowledged that the Council of State enjoys the same independence from executivebranch meddling as do the courts.

Litigation in the Council of State is conceived in markedly different terms from litigation in the ordinary courts. Traditionally, administrative litigation was understood primarily as designed to guarantee the legality and propriety of government action in a republican system faithful to the rule of law. In other words, administrative litigation was perceived as serving "objective" purposes, linked to the correct working of the bureaucracy within the overall system of government. Until recently, the "subjective" purposes of promoting justice and safeguarding individual rights were believed to be secondary. This has had numerous consequences for the system of administrative law adjudication. The fact that an administrative decision takes the form of a generally applicable regulation, affecting broad classes of individuals based on general characteristics, is not a barrier to getting into court (standing) as in other countries, such as Germany, England, and, in the past, the United States. Because of the focus on the objective lawfulness of rules, any individual affected by a rule can come forward to contest its correctness. Another consequence of this stylization of administrative adjudication was, until recently, a fairly meek system of judicial remedies. Before 1980, 
the Council of State could annul offending administrative acts but it did not have the procedural tools necessary to force administration to come into compliance and guarantee that victorious litigants would obtain relief from wrongful government action. Since the 1980s, however, the Council of State has gradually acquired a better remedial toolkit, first with the power to fine non-compliant administration (astreinte), then with the power to issue injunctions (injonction), and finally with the power to grant temporary injunctions (référé).

Mirroring the institutional separation between the judiciary and the Council of State, the study and doctrinal elaboration of administrative law in France is marked by a self-conscious divide between public and private law. In public law thinking, state administration is granted extraordinary privileges (the prerogatives of the puissance publique) but is also subject to extensive duties designed to safeguard the rights and interests of citizens. One clear example of this is the important concept of "public service." ${ }^{10}$ The notion of public service was invented to cover any state activity performed in the general interest, not simply the core functions of policing and defense. Once a government activity is classified as a "public service," the state is empowered to take whatever measures are necessary to ensure the continuity of that service and adaptation to changing circumstances, but it is also under a duty to treat the citizen-users of the public service equally and neutrally. To ensure continuity and adaptability, the administration is permitted to unilaterally modify government contracts with private providers but it is also required to compensate the provider for any loss suffered as a consequence.

Linked to this understanding of the special concerns of public law is the sweeping scope of the field. In contrast with common law systems like the United States, where public contracts and government liability are taught as specialty subjects and are omitted from most administrative law textbooks, in the French tradition, state liability and government contracts are integral to the discipline. The theoretical apparatus of government privileges and duties at the core of administrative law extends to all forms of administrative action and all attempts to obtain individual redress from government wrongs. As many have observed, however, public law is coming to borrow more and 
more from private law and therefore, even in France, public contracts and governmental liability are losing some of their distinctiveness. ${ }^{11}$

An alternative that has emerged to the English and French models of judicial review is that of a specialized branch of the judiciary dedicated to hearing administrative law cases. ${ }^{12}$ The first example is generally taken to be Germany. There the judicial branch is composed of the Federal Constitutional Court and five discrete judicial hierarchies, one for civil and criminal law, one for labor disputes, one for tax disputes, one for social security disputes, and one for administrative law disputes. The latter three all handle variants of what would be called administrative law cases in other countries. The judges that serve on the tax, social security, and administrative law courts are recruited based on the same system of university study, exams, and traineeships as their counterparts on other courts and share the same, identical guarantee of independence. The only difference is the degree of specialization and familiarity that the members of these three branches acquire with administrative disputes.

The systems in this third category operate closer to the common law model than the French one. In Germany as well as other countries that have chosen to adopt a specialized judiciary, government contract and tort disputes are heard by the civil courts, not by the administrative courts, and the doctrine tracks the private law of contract and tort. Moreover, administrative litigation is designed to protect individual rights and interests, much as private law litigation, and therefore the conditions under which standing is granted are more limited than in French law while, at the same time, the remedial powers of courts are broader.

Most legal systems have adopted one of these three institutional models. Histories of colonial rule can go some way in explaining the patterns that we see today. The territories that were part of the British Empire and that adopted the common law have entrusted generalist courts with hearing disputes between individuals and public administration. These include Australia, New Zealand, India, Ireland, and the United States. Due to the influence of American law after World War II, a number of other countries have adopted the generalist court model, including Japan and South Korea. Countries influenced by France in the 1800s and the first half of the 1900s today have Councils of State that operate separate from the judiciary. These include Belgium, the 
Netherlands, Luxembourg, Italy, Greece, Turkey, Lebanon, Egypt, Colombia, Morocco, Algeria, and Senegal. ${ }^{13}$ However, the label can be deceptive, since some of these Councils of State only have policymaking powers (e.g., Luxembourg) and some only have powers of adjudication and are housed within the generalist court of last resort for civil and criminal disputes (e.g., Morocco, Algeria, Senegal). Moreover, unlike the French model, jurisdiction over government liability cases in Belgium, Italy, and the Netherlands is vested in the courts, not the Council of State, on the liberal theory that the ordinary courts are better placed to protect property and other rights against oppressive state action. It appears that the system of a specialized, administrative law branch of the judiciary, illustrated above with the German case, is even more widespread that the other two models: it has been adopted in Austria, Portugal, Sweden, Finland, Czech Republic, Poland, Spain, Switzerland, Hungary, Slovenia, Romania, Estonia, and most of Latin America.

\subsection{Principles of administrative action}

\subsubsection{Procedural principles}

Traditionally, one of the differences that separated the common law from continental legal systems was its reliance on procedural principles of fair play in judging the correctness of administrative action. ${ }^{14}$ The common law tended to equate important categories of administrative action with the adjudication of courts and to require analogous procedural safeguards. By contrast, the administrative law of continental Europe was more focused on the substantive correctness of administrative decisions in deciding whether to let them stand. ${ }^{15}$ In English law, this procedural emphasis was encapsulated by the principle of natural justice, which included the right to be heard and the right to an impartial adjudicator, also known as the rule against bias. In American law, these same guarantees have been developed in the constitutional case law on procedural due process. Although the French Council of State began fashioning procedural requirements for government administration as far back as 1944, with a line of cases on the "rights of the defense" (droits de la défense), these rights were more limited than their common law counterparts: they generally excluded rights to an oral hearing 
and the disclosure of documents and they only applied to those administrative decisions that were cast as imposing sanctions.

Since the 1970s, however, this common law-continental law difference has faded. A number of national laws guarantee individuals, in the context of an individualized administrative determination, the right to receive notice of the proposed decision, to examine the supporting documents, to respond in writing, and to receive a statement of reasons with the final decision. These include French laws of July 11, 1979 and April 12, 2000, the Italian law of August 7, 1990, the Swedish Administrative Procedure Act of 1986, and the Danish Public Administration Act of 1985. The German case is somewhat exceptional in that the proceduralization of individual decisionmaking began immediately in the post-war period, under the heavy influence of constitutional law, and was eventually codified with the Federal Administrative Procedure Act of 1977. Spain is another interesting case: Already in 1889, notice and hearing procedures for licensing, procurement, and other types of individualized decisions were set down in the Spanish Administrative Procedure Act. A number of countries in Latin America and East Asia have also adopted administrative procedure laws: Peru in 1972, Argentina in 1973, Costa Rica in 1978, Columbia in 1984, Japan in 1993, and South Korea in 1995. ${ }^{16}$

Notwithstanding this common trend, at least one important difference remains. Common law countries have institutionalized the judicial model within the administrative process to a greater extent than other legal systems. In Britain and Australia this takes the shape of administrative tribunals, while in the United States it comes under the heading of "formal adjudication," governed by the Administrative Procedure Act and handled by administrative law judges. ${ }^{17}$ Administrative tribunals and administrative law judges are responsible for hearing appeals from social security determinations, immigration decisions, and other high-volume regulatory areas and their decisions are subject to judicial review on points of law before the ordinary courts. They are formally part of government administration even though they enjoy significant statutory guarantees of independence and their decisionmaking procedure is modeled after the courtroom. This institutionalization of dispute resolution stands in contrast with continental bureaucracies, where there is generally a right of appeal up the chain-of- 
command to administrative superiors, but where the main opportunity for an independent hearing is in judicial review before a full-fledged court.

\subsubsection{Substantive principles}

In reviewing the substance of an administrative decision to ban a product on safety grounds, to deny a building permit for a supermarket, or to accomplish one of the thousands of other purposes of bureaucracy, what criteria do courts use? ${ }^{18}$ A multitude of doctrinal headings are used by courts to examine the substance of administrative decisions and decide whether or not to let them stand. Nevertheless, the intervention of courts in the activity of bureaucracy can be seen to fall under three distinct headings: rule of law, individual rights, and policy rationality. In the section below, I explore the local expressions of these judicial review practices and discuss the important variations in how and the extent to which these powers are exercised.

Much judicial review is geared towards furthering the rule of law, understood as the principle of a government of laws and not of men. ${ }^{19}$ Public administration must respect the purposes and limits set down in laws_-generally passed by parliaments, but also, in some places executive decrees — or turn into the arbitrary action of tyrannical despots. The task of courts is to enforce those limits. To understand the pervasiveness of this understanding of the relationship between courts and the bureaucracy, it suffices to peruse the main types of challenges contemplated in the administrative law of France, the United States, and England. Administrative acts can be overturned in France in the case of "incompetence" or a "violation of the law," excess of statutory jurisdiction, authority, or limitations, or short of statutory right" 21 and in England if the court finds an "error of law" 22 or "illegality." 23 Thus to take an example from American administrative law, in 2000, the Supreme Court struck a regulation of the Food and Drug Administration severely restricting the sale and advertising of tobacco products on the grounds that the statute under which the government was acting could only be interpreted to give it authority over medical drugs, not tobacco. ${ }^{24}$ The same challenge would be styled as incompetence or a violation of law in France and an error of law or illegality in England. 
A second type of substantive review of administrative action is the protection of basic liberties against government action. This was true even in the absence of a written bill of rights enforceable by the courts, as was the case in most countries until the 1950s, given the importance of property rights in both the common law and civil law codes. With the spread of written constitutions in the twentieth century, as well as international human rights instruments, in particular the European Convention of Human Rights, the catalogue of rights that courts are expected to defend against administrative action has expanded: freedom of expression and association, the right to privacy and human dignity, personal liberty, the right to engage in the trades, and much more. All of these rights can be readily breached by the decisions of immigration authorities, social security agencies, licensing boards, and other government bodies and they are commonly invoked before the courts.

On this aspect of judicial review, let us dwell on Germany for a moment, where fundamental rights guarantees are particularly pervasive and administrative law has been thoroughly constitutionalized, more so than in other European systems and the United States. The most conspicuous sign of this is probably the declaration, made in 1959 by the President of the Federal Administrative Court, that administrative law is "concretised constitutional law" (konkretisiertes Verfassungsrecht). ${ }^{26}$ The German courts have developed a number of cross-cutting principles that are designed to limit administrative action to the benefit of individual liberties. Three in particular bear mention: proportionality, equality, and legitimate expectations.

Any measure that interferes with a right must satisfy a proportionality test. In this sequential inquiry, the government must demonstrate that the measure is capable of achieving the declared public ends; that it is necessary to achieve those ends and that no other, equally effective and less rights-restrictive measures are available for accomplishing the same purposes; and that the public benefit from the measure outweighs the burden to the individual right. Thus, for instance, in the domain of administrative sanctions, the Federal Constitutional Court has held that the forfeiture of unemployment benefits for two weeks, in response to the recipient's failure to notify regularly the public employment office of his employment status, was disproportionate. To take another example, in 1958, the Constitutional Court declared a restriction on the number of 
pharmacies a disproportionate interference with the right to freely choose one's profession. The German courts engage in a similar inquiry when administrative programs are challenged due to alleged discrimination based on economic or other characteristics: under the equality principle "[d]ifferences must be of such a kind and weight so as to justify a differentiation." ${ }^{27}$ And the principle of legitimate expectations, the rough equivalent of the duty of non-retroactivity and the protection of reliance interests in the United States, and derived in Germany from the rule of law and the right to freedom of action, significantly limits the ability of public administration to reverse benefit-conferring determinations. As a result of this legal doctrine, beneficiaries of public programs involving agricultural subsidies, housing benefits, and other types of entitlements have a right to significant notice (generally one year) or compensation before the government may alter the terms of the program or withdraw a benefit improperly granted. ${ }^{28}$

These rights, albeit with numerous modifications and with significant differences in judicial practice, have gone on to influence the case law of the European Court of Justice and other European legal systems. ${ }^{29}$ The constitutionalization of European administrative law stands in marked contrast with the United States, where the Supreme Court is highly deferential to government action that burdens the economic rights protected under the Fourteenth Amendment of the Constitution. ${ }^{30}$ These are the very rights that are most commonly implicated by administrative determinations yet so-called "rational basis" review under the Fourteenth Amendment is a tremendously lenient standard when compared to the principles of proportionality and equality in German law.

The last form of judicial review of administrative action is review for policy rationality. Doctrinally, rationality review picks up where legality review leaves off: when controlling legislation does not contain standards to guide administrative action and thus effectively leaves decisionmaking to bureaucratic discretion, the courts nonetheless can evaluate administrative action based on criteria related to sound policymaking. Doctrinal expressions of this form of review give the impression that only acts of confirmed insanity will be struck by the courts: review for "arbitrary and capricious" decisionmaking in the United States ${ }^{31}$ and review for "manifest error of assessment" 
(erreur manifeste d'appréciation) in France. ${ }^{32}$ Even better is the English articulation of the principle:

By "irrationality" I mean what can now be succinctly referred to "Wednesbury unreasonableness".... It applies to a decision which is so outrageous in its defiance of logic or accepted moral standards that no sensible person who had applied his mind to the question to be decided could have arrived at it... ${ }^{33}$

In the United States, however, arbitrary and capricious review has become a demanding test, and, indeed, it has come to represent a distinctive feature of the American administrative law system. It became common judicial practice in the late 1960s and the 1970s and was associated with the fall of the post-war consensus on economic growth, growing distrust in technologies and government, new social movements such as the environment and civil rights, and the spread of public interest lawyering. The Supreme Court's statement in State Farm remains the emblematic articulation of arbitrary and capricious review of administrative policymaking in American law:

the agency must examine the relevant data and articulate a satisfactory explanation for its action including a 'rational connection between the facts found and the choice made.' . . Normally, an agency rule would be arbitrary and capricious if the agency has relied on factors which Congress has not intended it to consider, entirely failed to consider an important aspect of the problem, offered an explanation for its decision that runs counter to the evidence before the agency or is so implausible that it could not be ascribed to a difference in view or the product of agency expertise. . .$^{34}$

In State Farm, the Supreme Court struck an administrative decision revoking a passenger-safety rule requiring automobiles to be fitted with automatic seatbelts or airbags. It found that the tests and studies in the agency's record did not support a 
determination that the rule would fail to produce safety benefits and it faulted the agency for failing to consider other policy options for ensuring passenger safety, namely an airbag-only rule.

Although European rights-based proportionality review and American arbitrary and capricious review overlap in some respects, their essence is fundamentally different. In the former, the focus is on the individual right and the decision to overturn the administrative act turns on an assessment of the importance of the right as compared to the public purpose as well as the ability of the administration to articulate a close connection between the government measure and the public purpose. In the latter, the focus is on the quality of the science and policymaking assessments behind the administrative decision and the ability of the government to justify its chosen course of action in the face of alternative scientific evidence and policy options put forward by its opponents.

\section{Administration and Organized Interests}

In the conventional image of public administration, bureaucrats and courts are the main protagonists. State officials deploy their considerable expertise and technical prowess to accomplish public purposes and courts watch over them to ensure that they stay within the four corners of the law. The role of social and economic groups in administrative governance has traditionally been ignored in legal scholarship, largely because the theories of democracies used to legitimate administration cast elections, representative assemblies, and independent courts as the primary agents of democracy and tend to regard interest groups with suspicion.

A growing literature, however, now recognizes that many elements of administrative law are designed to enable social and economic actors to inform and participate in administrative governance and that the legitimacy of administration rests as much on accountability to civil society as it does on judicial review and legislative oversight. $^{35}$ Industry associations, trade unions, professional associations, environmental and consumer groups, and various other actors are routinely called upon to advise on government rulemaking, manage public programs, and engage directly in standard-setting and rule-enforcement through powers of self-regulation. Due to space constraints, this 
section will address only one of these forms of administrative law: the procedures that empower social and economic groups to participate in government rulemaking.

A distinctive feature of American administrative law is what is known as noticeand-comment rulemaking. Before administrative agencies decide on the new policies contained in government rules - for instance, worker-safety standards for coal mines, maximum chemical concentrations for drinking water, and consumer protection rules for the banking industry - they must first give notice of the proposed rule, allow the public an opportunity to comment on the rule, and respond to any objections in a "concise general statement" explaining the rationale for the rule. ${ }^{36}$ If commenters are disappointed with the final result, they may go to court. Besides reviewing the rule on the substantive grounds discussed in the previous section, the court will also decide whether the agency adequately responded to the public comments or, if no such procedure was held, whether the administration was correct in deciding that one of the exceptions to the requirement of notice-and-comment rulemaking applied. Thus notice-and-comment rulemaking significantly limits administrative discretion, both on when and whom to consult and on what weight, if any, to give to objections from the regulated community. Although notice-and-comment rulemaking is formally open to anyone, a number of studies have found that, in practice, organized interests and market actors are the main participants, both because of the resources necessary to respond convincingly to administrative proposals and, in the event of defeat, call the administration to task before the courts, and because of the broad-reaching and abstract nature of the policy being decided, which rarely prompts action from individual citizens. ${ }^{37}$

Notice-and-comment rulemaking was first introduced in 1946, with the adoption of the Administrative Procedure Act. It was then amplified in the 1960s and 1970s by a series of court decisions that required administration to alert the public to all aspects of a proposed rule and to give careful consideration to public comments in the administrative statement supporting the final rule. ${ }^{38}$ This judicial turn was driven by the sense that administration had been "captured" by industry actors and that public interest groups, which were rapidly proliferating at the time, should be guaranteed an equally prominent role in the policymaking process. ${ }^{39}$ The original creation and subsequent development of notice-and-comment rulemaking reflects what, in the political science literature, is known 
as the American system of pluralist interest representation. ${ }^{40}$ In the theoretical stylization of pluralism, multiple organizations, representing a variety of different interests, compete to influence government decisions in what, formally speaking, is a policymaking process open to all and government officials seek to neutrally mediate among these diverse interests. Pluralist thinkers like Arthur Bentley, David Truman, and Robert Dahl saw immense democratic promise in this system of interest group competition because they believed that government decisions would reflect the entire range of interests at play in the nation rather than cater to any one group or set of groups. Of course, as many have observed, this positive assessment rests on a number of often questionable assumptionsthat all groups are equally capable of mobilizing, that all organizations have the resources necessary to participate in the political process, and that government officials mechanically responding to self-regarding interests, even a wide variety of interests, is a process capable of generating morally worthy government policies. ${ }^{41}$ Nevertheless, the theory and practice of pluralism is extremely powerful in American politics and is reflected and perpetuated by legal procedures such as notice-and-comment rulemaking.

By contrast, in Europe, the favorite device for obtaining outside advice on government rules is the civil society committee. Established by law, these committees are composed of representatives of the major organizations active in the policy area and are generally chaired by a government bureaucrat. Their consultation can be either mandatory or optional, depending on the policy area and the type of government proposal, and they often also exercise powers of proposal. In France, Italy, the European Union, and other legal systems, there are hundreds of these committees in areas as diverse as welfare and industrial policy, consumer policy, environmental policy, and equal protection. To give but one example, in France, the High Council on Professional Equality Between Men and Women gives advice on new equal protection initiatives and is composed of nine members of the administration, nine members selected by the five major national trade unions, nine members chosen by a variety of employer organizations, and nine policy experts and representatives of women's rights organizations selected by the responsible government ministry. In committees such as the French High Council, the organizations entitled to comment on government policies are the handful mentioned in the enabling legislation or tapped by the administration to 
sit on the committee, and therefore influence over policymaking is more restricted than in notice-and-comment rulemaking, as it is limited to those groups that have established themselves as reputable and powerful members of the regulatory community. Moreover, unlike notice-and-comment rulemaking, which is mandatory for most forms of administrative rulemaking, consultation of civil society committees is often entirely within the discretion of public administration. And finally, while American officials must reply meticulously to comments or risk being sued, their European counterparts are not legally required to respond in any particular fashion to the comments and proposals authored by such committees.

It is certainly true that, today, European regulators also stage broad-based consultations, using the possibilities afforded by the internet to make their policy proposals widely known and to solicit the reactions of all those organizations that care to comment. ${ }^{42}$ Therefore the privileged access of the past through the committee system has been attenuated somewhat through the use of new technologies. However, in contrast with American notice-and-comment rulemaking, these consultations are permeated by administrative discretion, both in the decision to call them in the first place and subsequently, in the decision on what kind of response, if any, to give to public opposition. Regulators, therefore, are still in a strong position to control access to the policymaking process.

The institution of the civil society committee is rooted in the theory and politics of what, in the political science literature, is known as neo-corporatism. ${ }^{43}$ In many European countries, producer groups are represented by a few, all-encompassing and broadly representative labor unions, employer associations, farmer groups, and professional associations and these organizations are given an essential role in the policymaking process. As politics have changed and non-material interests have become more prominent, this model of all-encompassing organizations and privileged access has been extended to environmental and consumer protection groups, human rights organizations, and other types of associations. Neo-corporatist political theory portrayed the state and society as intertwined: public administration would nurture the many producer organizations upon which social cohesion and economic prosperity depended and, in turn, those producer groups would be entitled to influence the policies of the state. 
These ideas were developed in the law by thinkers such as Harold Laski in England, Otto von Gierke in Germany, Léon Duguit and Maurice Hauriou in France, and Santi Romano in Italy and stand in marked contrast with the portrayal of interest group politics as conflictual and government actors as passive arbiters in pluralist theories of democracy.

\section{Administration and the Public}

In a number of administrative law systems, informal, broad-ranging public oversight has become critical to the legitimacy of bureaucracy. Although this form of diffuse accountability is achieved through a wide range of legal tools and institutional arrangements, two are particularly prominent: ombudsmen appointed by parliaments with oversight and complaint-resolution functions and laws guaranteeing all citizens a right of access to government documents. Sweden is generally believed to be the first Western legal system to have established an ombudsman and freedom of information. There the expansion of parliamentary power and the establishment of a constitutional monarchy was accompanied by the passage of the Law on Liberty of the Press (1766, re-enacted in 1809), abolishing censorship and giving a right of public access to government documents, and the creation of a parliamentary ombudsman (1809). For a long time, Sweden stood out as an anomaly, but beginning in the 1970s, momentum got underway in a number of countries for broader public accountability in government administration and today a vast array of legal systems have freedom-of-information laws and ombudsmen.

Ombudsmen share a number of characteristics. ${ }^{44}$ They are institutionally linked to parliaments, not the executive branch, by virtue of the fact that they are appointed by parliament, generally for a fixed term, and are legally obligated to report periodically to parliament on their activities. The principal function of ombudsmen is to settle complaints filed by members of the public against the bureaucracy. The process is informal, in that a simple letter or online complaint form is sufficient to trigger an investigation and the grounds for complaining are extremely broad - anything linked to maladministration - and do not need to be styled as one of the grounds for obtaining legal redress in the courts. "The public officer was extremely rude" or "I never received an answer to the query that I filed with the tax office" is enough to warrant a response from 
the ombudsman. ${ }^{45}$ The ombudsman system, therefore, offers the promise of redress to individuals without the resources to go to court and in circumstances that fail to meet the stringent legal criteria that have been developed by courts to make a successful claim against the administration.

Once the ombudsman comes to a decision on a complaint, the powers of the office are limited compared to courts. The ombudsman cannot order civil servants to comply with his or her decision but rather must rely on bureaucratic good will and the threat of bad press and public embarrassment to induce compliance. ${ }^{46}$ The triangular relationship between the ombudsman, the press, and parliament is critical to ensuring the effectiveness of the institution. The threat of public censure and hostile parliamentary questions is the main tool in the ombudsman's arsenal and underscores the diffuse public accountability inherent in this area of administrative law. Ombudsmen in Sweden, France, Denmark and many other countries are also involved in policymaking and regularly recommend changes to administrative law and practice to bring administration into line with rule of law ideals and fundamental rights guarantees.

Laws on the right of access to public documents also broaden public oversight of administration. ${ }^{47}$ The right to government documents expands public scrutiny by giving individuals a right to examine the decisions of government even absent a claim of having been wronged or having a particular interest in the matter. Simply by virtue of being a citizen, individuals are assumed to have a stake in the correct workings of their government and are entitled to request government documents without having to put forward a justification for their request. Freedom-of-information laws, however, also restrict the types of documents that are accessible. For instance, documents filed with government by industry and containing commercial secrets and documents related to national security are either excluded from the right of access or subject to extensive redaction before they may be released to the public. Preliminary drafts, notes, and memoranda are entirely exempted from disclosure in Sweden and Denmark if they are not circulated outside the responsible government agency and are exempted until the relevant government decision becomes final in Finland and the United States. These laws also differ in how they organize access to documents: an official register of government documents, open to public consultation, exists in Sweden, Finland, and the 
European Union, but not in Denmark, the Netherlands, and the United States, where petitioners must designate the issue of interest and trust the responding agency to locate the relevant documents.

Both ombudsmen and freedom-of-information laws have been popular over the past decades. In Europe, Finland (1919), Denmark (1954), Britain (1967), France (1973), Spain (1981), the Netherlands (1984), Ireland (1984), Portugal (1991), and Romania (1991) have established ombudsmen at the national level, and other countries, like Germany and Italy, have established them at the regional level. New Zealand (1962), Hong Kong (1989), and Korea (1994) are examples of other countries with parliamentary ombudsmen. As for freedom of information, according to one study, almost seventy countries throughout the world have adopted the necessary legislation. ${ }^{48}$

These overviews give an idea not only of the extent of diffuse public accountability as a feature of administrative law, but also of the remaining variations. Legal systems still differ in the degree to which individuals seek formal recognition of their grievances through the courts or rely mostly on informal avenues of redress through ombudsmen. In some countries, parliamentary ombudsmen are absent, as in the United States and Germany (at the federal level), and in others, the ombudsman system is considered ineffective. By contrast, in countries like Sweden and Denmark, the informal administrative justice offered by ombudsmen is immensely popular and tends to function as a substitute for courts. Freedom-of-information laws also have not taken root everywhere. Just in Europe, Italy and Greece are notable exceptions to the trend.

\section{The Globalization of Administrative Law}

This discussion would be incomplete without mention of the accelerating diffusion of administrative principles among legal systems, spurred by the forces of globalization. Traditionally one of the reasons that public law was said to be the poor cousin of private law in comparative studies was that public law was too idiosyncratic and contingent on domestic politics and national history for comparison to yield any fruitful insights. There is no doubt that administrative law is profoundly shaped by distinct national experiences with state formation. Today, however, the rise of a liberal consensus and the growing power of international organizations have prompted political 
actors in a variety of jurisdictions to adopt a common set of good governance reforms involving administrative procedures and principles of judicial review. Therefore, at least on the books, administrative law appears to be converging.

Transparency, where the last section ended, is a good example of the globalization phenomenon. As explained earlier, legislation on the right of access to government documents was first adopted in Sweden in 1766 and it was immediately copied in Finland, which at the time was a Swedish colony. Two hundred years later, it still was limited to those two countries. Then, in the 1970s and 1980s, the United States and a handful of other European countries adopted freedom-of-information legislation. In 1993, the European Union followed suit, obliging not only its own institutions to hand over documents to the public, but also putting heavy pressure on all of its member countries to do the same. Since then, the United Nations, the Organization of American States, and a number of other international organizations have urged their member countries to adopt freedom-of-information laws. By 2006, one survey found that nearly seventy countries had such laws and an additional fifty countries were in the process of drafting them. ${ }^{49}$ And according to a recent analysis, the many transnational and international regulatory authorities that have sprung up over the past decades also have made commitments to transparency. ${ }^{50}$ In sum, since the $1990 \mathrm{~s}$, the right of access to government documents has become a commonplace of public life and this is due in no small measure to the growing influence of international bodies in world politics.

One of the main challenges facing comparative law scholars today is to understand the operation, utility, and ultimately, desirability of these common procedures and principles in the multiple legal settings in which they now exist. To do so, it is necessary for comparative scholarship to move beyond the traditional national focus and to recognize the growing importance of international legal systems as objects of study in their own right and as catalysts for change at the domestic level. At bottom, however, comparative law is well equipped to handle this new task. It requires a deep appreciation of the historical diversity of national legal traditions and a familiarity with the many ways in which legal transplants can be transformed in the process of migration from one place to another. These are concerns that have traditionally been at the heart of comparative 
law scholarship and that offer an essential platform for coming to grips with globalization.

\footnotetext{
${ }^{1}$ S. Skowronek, Building a New American State: The Expansion of Administrative Capacities, 1877-1920 (Cambridge: Cambridge University Press,1982); J. Ziller, Administrations comparées: Les systèmes politico-administratifs de l'Europe des Douze (Paris: Montchrestien,1993).

${ }^{2}$ R. Rose, 'Giving Direction to Government in Comparative Perspective', in J.D. Aberbach and M.A. Peterson (eds.), The Executive Branch (New York: Oxford University Press, 2005), 72.

${ }^{3}$ S. Battini, 'Il Personale', in L. Torchia (ed.), Il Sistema Amministrativo Italiano (Bologna: Mulino, 2009), 279; S. Cassese, 'Hypotheses on the Italian Administrative System', (1993) 16 West European Politics 325.

${ }^{4}$ E. Suleiman, Dismantling Democratic States (Princeton: Princeton University Press, 2003).

${ }^{5}$ M. Minow, 'Outsourcing Power', in J. Freeman and M. Minow (eds.), Government by Contract: Outsourcing and American Democracy (Cambridge: Harvard University Press, 2009), 110; S. Dolovich, 'State Punishment and Private Prisons', (2005) 55 Duke Law Journal 441.

${ }^{6}$ See, e.g., S. Cassese, 'La costruzione del diritto amministrativo: Francia e Regno Unito', in S. Cassese (ed.), Trattato di diritto amministrativo, 2nd ed., vol. I (Milan: Giuffré, 2003), 1-93; M. d'Alberti, Diritto amministrativo comparato (Bologna: Il Mulino, 1992); J.D.B. Mitchell, 'The Causes and Effects of the Absence of a System of Public Law in England', (1965) Public Law 95, 96-101.

${ }^{7}$ Introduction to the Study of the Law of the Constitution (London: Macmillan, 1885).

${ }^{8}$ M. Taggart, 'The Peculiarities of the English: Resisting the Public/Private Law Distinction', in P. Craig and R. Rawlings (eds.), Law and Administration in Europe: Essays in Honour of Carol Harlow (Oxford: Oxford University Press, 2003), 107.

${ }^{9}$ This discussion of the Council of State is drawn largely from M. Fromont, Droit administratif des États européens (Paris: Thémis, 2006).

${ }^{10}$ J.S. Bell, 'Comparative Administrative Law', in M. Reimann and R. Zimmerman (eds.), The Oxford Handbook of Comparative Law (New York: Oxford University Press, 2006) 1261, 1274.

${ }^{11}$ See, e.g., E. Picard, 'The Public-Private Divide in French Law Through the History and Destiny of French Administrative Law', in M. Ruffert (ed.), The Public-Private Law Divide: Potential for Transformation? (London: BIICL, 2009), 17.

${ }^{12}$ Fromont, Droit administratif des États européens, p. 128.

${ }^{13}$ Y. Gaudemet, 'L'exportation du droit administratif français: Breves remarques en forme de paradoxe', in Mélanges Philippe Ardant: Droit et politique a la croisée des cultures (Paris: LGDJ, 1999), 431.

14 This discussion only covers procedural rights in individualized administrative determinations since they originated historically with courts and the standards of fair administrative action imposed by courts. For the comparative procedure of administrative rulemaking, where the initiative has rested largely with legislatures, see the next section.

${ }^{15}$ D. Custos, 'Droits administratifs:américain et français: sources et procédure', (2007) Revue internationale de droit comparé 285, 295-96.

${ }^{16}$ A.R. Brewer-Carias, Etudes de droit public comparé (Paris: LGDJ, 2001); T. Ginsburg, 'Dismantling the "Developmental State"? Administrative Procedure Reform in Japan and Korea', (2001) 48 American Journal of Comparative Law 585.

${ }^{17}$ Peter Cane, 'Judicial Review in the Age of Tribunals', (2009) Public Law 479.

${ }^{18}$ Due to space constraints, the principles of government torts and public contracts are omitted from this discussion.

${ }^{19} \mathrm{I}$ take this as the lowest-common-denominator definition of rule of law. It is also important to note, however, that the definition varies considerably from one legal system to the next. Among the most comprehensive conceptions is probably the German one, which includes substantive principles of fundamental rights and social justice as part of the definition of "law" and which does not recognize
} 
inherent executive powers, but rather requires that all administrative action be authorized by parliamentary law. Bell, 'Comparative Administrative Law', p. 1272.

${ }^{20}$ Fromont, Droit administratif des États européens, p. 167.

${ }^{21}$ Administrative Procedure Act $\$ 706(2)(B)$.

${ }^{22}$ P. Craig, Administrative Law, $6^{\text {th }}$ ed. (London: Sweet \& Maxwell, 2008), 437.

${ }^{23}$ P. Craig, Administrative Law, $6^{\text {th }}$ ed. (London: Sweet \& Maxwell, 2008), 531-549.

${ }^{24}$ Food and Drug Administration v. Brown and Williamson Tobacco Corp., 120 S.Ct. 1291 (2000). Here, as in most statutory interpreation cases, the Supreme Court did not specify which of the judicial review provisions of the Administrative Procedure Act were being applied but rather relied on its precedent.

${ }^{26}$ For this and the rest of the discussion of German law, see G. Nolte, 'General Principles of German and European Administrative Law-A Comparison in Historical Perspective', (1994) 57 The Modern Law Review 191, 201.

2785 BVerfGE 191, 210 (1992).

${ }^{28}$ E.J. Eberle, 'The West German Administrative Procedure Act: A Study in Administrative Decision Making', (1984) 3 Dickinson Journal of International Law 67.

${ }^{29}$ See A. Sandulli, La proporzionalità dell'azione amministrativa (Padova: Cedam, 1998); J. Schwarze, European Administrative Law (London: Sweet \& Maxwell, 1992).

${ }^{30}$ See B. Ackerman, We the People: Transformations (Cambridge: Harvard University Press, 1998).

${ }^{31}$ Administrative Procedure Act $\$ 706(A)(2)$. It should be noted that, doctrinally speaking, arbitrary and capricious review is required under the Administrative Procedure Act and is unrelated to weak rationalbasis review under the Constitution.

${ }^{32}$ Ziller, Administrations comparées, p. 296.

${ }^{33}$ Council of Civil Service Unions v Minister for the Civil Service [1985] AC 374, Lord Diplock.

${ }^{34}$ Motor Vehicle Manufacturers Ass'n v. State Farm, 463 U.S. 29, 42(1983).

${ }^{35}$ See, e.g., J. Freeman, 'Collaborative Governance in the Administrative State', (1997) 45 University of California Los Angeles Law Review 1.

${ }^{36}$ Administrative Procedure Act $§ 553$.

${ }^{37}$ J. Webb Yackee and S. Webb Yackee, 'A Bias Towards Business? Assessing Interest Group Influence on the U.S. Bureaucracy', (2006) 68 Journal of Politics 128; M.-F. Cuellar, Rethinking Regulatory

Democracy, (2005) 57 Administrative Law Review 411.

${ }^{38}$ See, e.g., U.S. v. Nova Scotia Food Products, 568 F.2d 240 (2d Cir. 1977).

${ }^{39}$ R.B. Stewart, 'The Reformation of American Administrative Law', (1975) 88 Harvard Law Review 1669.

${ }^{40}$ Stewart, 'The Reformation of American Administrative Law', p. 1669.

${ }^{41}$ See, e.g., R.B. Stewart, 'Madison's Nightmare', (1990) 57 University of Chicago Law Review 335.

${ }^{42}$ See, e.g., D. Rubinstein Reiss, 'Participation in Governance from a Comparative Perspective: Citizens Involvement in Telecommunications and Electricity in the United Kingdom, France and Sweden', (2009) Journal of Dispute Resolution 381.

${ }^{43}$ P.C. Schmitter, 'Still the Century of Corporatism?', in P.C. Schmitter and G. Lehmbruch (eds.), Trends Toward Corporatist Intermediation (London: Sage, 1979), 13; W. Streeck, 'The study of organized interests: before 'The Century' and after', in C. Crouch and W. Streeck (eds.), The Diversity of Democracy (Cheltenham: Edward Elgar, 2006) 3, 17-18, 29-30.

${ }^{44}$ Early accounts include W. Gellhorn, Ombudsmen and Others: Citizens' Protectors in Nine Countries (Cambridge: Harvard University Press, 1966) and D. Rowat, The Ombudsman: Citizen's Defender (London: George Allen \& Unwin Ltd., 1968). A good example of the more recent literature is K. Heede, European Ombudsman: Redress and Control at the Union Level (The Hague: Kluwer, 2000).

${ }^{45}$ See, e.g., The European Ombudsman, The European Code of Good Administrative Behavior, art. 12.

${ }^{46}$ On the enforcement dimension, the powers of the Swedish ombudsman are exceptional because it can initiate disciplinary proceedings or bring criminal prosecutions against individual civil servants and therefore it is more powerful than most of its peers.

${ }^{47}$ J.M. Ackerman and I.E. Sandoval-Ballesteros, 'The Global Explosion of Freedom of Information Laws', (2006) 58 Administrative Law Review 85.

${ }^{48}$ Privacy International (David Banisar), Freedom of Information Around the World 2006: A Global Survey of Access to Government Information Laws, available at http://www.freedominfo.org/documents/global_survey2006.pdf.

${ }^{49}$ Privacy International, Freedom of Information. 
${ }^{50}$ B. Kingsbury, 'The Concept of "Law" in Global Administrative Law', (2009) 20 European Journal of International Law 23. 